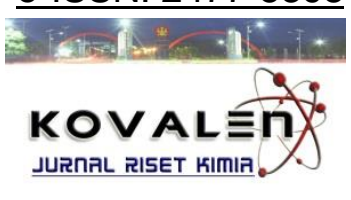

\title{
MIKROENKAPSULASI EKSTRAK LIKOPEN BUAH TOMAT (Lycopersicum pyriforme) TERSALUT TEPUNG RUMPUT LAUT Eucheuma cottonii
}

\section{[Microencapsulation of Lycopene Extract from Tomato (Lycopersicum pyriforme) Coated by Eucheuma cottonii Flour]}

\author{
Ni Ketut Sumarni ${ }^{1}$, Novitaliani Kea $^{1^{\star}}$, Syaiful Bahri ${ }^{1}$ \\ 1) Jurusan Kimia, Fakultas MIPA, Universitas Tadulako, Palu \\ J. Soekarno Hatta Km.9, Kampus Bumi Tadulako Tondo Palu, Telp. 0451- 422611 \\ *)Coresponding author: Noviekea29@gmail.com (082194446029)
}

Diterima 30 November 2018, Disetujui 7 Februari 2019

\begin{abstract}
Lycopene is a natural compound that is susceptibly damage due to the temperature and the length of storage. It can be maintained by coating with seaweed flour using microencapsulation method. The aim of research is to determine the highest efficiency of lycopene microencapsulation based on the ratio of lycopene and seaweed flour as a coating agent. Microencapsulation was conducted using freeze drying technique. The ratio of lycopene extract and seaweed flour was 1:5, 2:5, 3:5, 4:5 (w/w), respectively and continued in storage room temperature for four weeks. The result indicated that the highest efficiency ratio was at 1:5 with percentage of $10.686 \%$ and kinetics degradation of lycopene coated seaweed flour following the reaction of zero order.
\end{abstract}

Keyword: Lycopene extract, seaweed flour, microencapsulation

\begin{abstract}
ABSTRAK
Likopen merupakan senyawa bahan alam yang mudah mengalami kerusakan akibat perubahan suhu dan waktu simpan. Kerusakan tersebut dapat diatasi dengan proses mikroenkapsulasi menggunakan penyalut, salah satunya tepung rumput laut. Tujuan dari penelitian ini untuk menentukan efisiensi penyalutan tertinggi berdasarkan rasio likopen terhadap tepung rumput laut. Metode penyalutan dilakukan menggunakan freeze dryng, dengan rasio likopen terhadap tepung rumput laut 1:5; 2:5; 3:5; $4: 5$ atas dasar (b/b). Analisis kadar likopen dalam mikrokapsul dilakukan selama 4 minggu. Hasil analisis menunjukan bahwa efisiensi penyalut tertinggi pada rasio $1: 5$ dengan persentase $10,686 \%$ dan kinetika degradasi likopen tersalut tepung rumput laut mengikuti kinetika reaksi orde nol.
\end{abstract}

Kata kunci: Ekstrak likopen,tepung rumput laut, mikroenkapsulasi. 


\section{LATAR BELAKANG}

Tomat adalah salah satu jenis sayuran yang memiliki kandungan senyawa antioksidan yang tinggi, seperti karotenoid (likopen, $\alpha$-karoten, $\beta$-karoten), flavonoid, dan vitamin. Kandungan likopen menyebabkan buah tomat berwarna merah, dalam 100 gram tomat segar ratarata mencapai 3-5 mg (Giovannucci, 1999). Likopen bersifat tidak stabil terhadap oksigen, panas dan cahaya sehingga membatasi penggunaannya dalam produk pangan, pangan fungsional dan farmasi (Yuan et al., 2008). Salah satu usaha yang dapat dilakukan untuk meningkatkan kestabilannya adalah dengan cara mikroenkapsulasi menggunakan penyalut salah satunya adalah tepung rumput laut.

Rumput laut jenis Eucheuma cottonni memiliki kandungan senyawa karaginan jenis kappa-karaginan yang cukup tinggi, yaitu dapat mencapai 50\% atas dasar berat kering. Kappa-karaginan merupakan jenis olahan rumput laut yang saat ini memiliki nilai jual $10-20$ kali lebih tinggi daripada harga rumput laut. Kualitas Eucheuma cottonni ditentukan oleh kandungan senyawa karaginan atau kappa-karaginan yang terkandung didalamnya. Semakin tinggi kandungan karaginan, mana mutu ramput laut akan semakin tinggi (Samsuar, 2006).

Karaginan dari rumput laut mudah terhidrolisis, tetapi stabil dalam bentuk gel (Glicksman, 1983). Sifat inilah yang berhubungan dengan kemampuannya sebagai bahan penyalut dalam pembuatan mikrokapsul.

Mikroenkapsulasi adalah suatu teknik penyalutan zat aktif dengan agen penyalut yang umumnya berupa senyawa polimer. Bahan penyalut menjadi bahan penting yang harus diperhatikan karena akan mempengaruhi ukuran dan stabilitas dari mikrokapsul (Caldeira, 2007). Selain jenis penyalut faktor yang berpengaruh dalam mikroenkapsulasi adalah rasio bahan inti terhadap penyalut. Metode pembuatan mikrokapsul dapat dilakukan dengan konsenvarsi pemisahan fase, semprot kering, semprot beku, emulsifikasi sistem penguapan, suspense udara, proses multi lubang sentifugal, penyalutan dalam panci dan polimerisasi (Lachman et al., 1994), dalam penelitian ini digunakan tween 80 sebagai emulsifier.

Menurut Rahmat (2018) tentang penggunaan karaginan sebagai penyalut ekstrak likopen buah semangka (Citrullus vulgaris Schard) menghasilkan nilai efisiensi penyalutan ekstrak likopen dengan karaginan terbaik adalah pada perbandingan 1:0,5 yaitu $82,64 \%$.

\section{METODE PENELITIAN}

\section{Bahan dan Peralatan}

Bahan yang digunakan mencakup: buah tomat (Lycopersicum pyriforme), rumput laut (Eucheuma cottonii), aquades, n-heksan, aseton, air, aluminium foil dan kertas saring.

Alat yang digunakan mencakup: spektrofotometer UV-VIS, pengering beku 
(freeze dryer), blender, kain saring, termometer, rotary vakum evaporator, neraca ohaus, neraca analitik, hotplate, shaker, plat kaca, oven, mesin kocok, panci, kompor, baskom, pisau, ayakan 60 mess dan alat-alat gelas yang biasa digunakan dalam laboratorium.

\section{Produksi Tepung Rumput Laut Modifikasi (Rizal et al., 2010)}

Rumput laut kering dicuci dengan air bersih dan direndam selama tiga hari. 40 gram rumput laut basah ditambahkan dengan 1 liter air dan di panaskan selama 1 jam. Rumput laut yang telah dipanaskan lalu dihancurkan menggunakan blender dan dipanaskan kembali selama 1 jam. Disaring untuk memisahkan antara filtrat dan ampasnya. Filtrat dipekatkan hingga $1 / 2$ volume awal dengan cara pemanasan. Filtrat hasil pemekatan dioles tipis di atas plat kaca kemudian keringkan di oven pada suhu $70^{\circ} \mathrm{C}$. Rumput laut yang telah kering dihancurkan dengan menggunakan blender sampai berbentuk tepung, kemudian diayak menggunakan ayakan 60 messh sehingga dihasilkan tepung rumput laut. Terakhir, ditentukan rendemennya menggunakan persamaan berikut :

$\%$ Rendemen $=\frac{\text { Massa tepung rumput laut }(\mathrm{g})}{\text { Massa rumput laut kering }(\mathrm{g})} \times 100 \%$

\section{Ekstraksi Likopen dari Buah Tomat (Daniel et al., 2017)}

Buah tomat yang sudah bersih ditimbang, ditambahkan air dengan rasio air terhadap buah tomat (rasio air/buah tomat) $1: 1$ atas dasar volume/berat
$(\mathrm{L} / \mathrm{kg})$. Buah tomat dihancurkan dengan blender, kemudian pasta tomat yang diperoleh dipanaskan pada suhu $70^{\circ} \mathrm{C}$ selama 30menit, selanjutnya disaring dan ampas atau residu yang dihasilkan dikeringkan dengan alat pengering surya. Residu kering merupakan likopen kasar dihancurkan dengan blender. Likopen dalam likopen kasar diekstraksi secara maserasi menggunakan pelarut campuran heksan/aseton 2:1 (v/v), dan disimpan selama 3×24 jam. Ekstrak likopen yang dihasilkan dipisahkan pelarutnya secara vakum dengan rotari vakum evaporator, hingga diperoleh ekstrak pekat, selanjutnya di simpan pada pada suhu dingin. Rendemen ekstrak dihitung menggunakan persamaan :

$\%$ Rendemen $=\frac{\text { Berat ekstrak kental }(\mathrm{g})}{\text { berat tepung buah tomat kasar }(\mathrm{g})} \times 100 \%$

\section{Mikroenkapsulasi Ekstrak Likopen dengan Penyalut Tepung Rumput Laut (Irsyad, 2017)}

Mikroenkapsulasi likopen dilakukan menggunakan metode pengering beku (freeze drying). Selanjutnya ekstrak likopen di campurkan rumput laut dengan perbandingan ekstrak likopen/rumput laut (b/b) (1:5), (2:5), (3:5), (4:5). Ekstrak likopen dicampur rumput laut dalam gelas kimia, diaduk menggunakan magnetik stirrer selama 1 jam dan ditambahkan tween 80 kemudian disimpan pada penyimpanan beku 3×24 jam. Campuran dikeringkan menggunakan freeze drying. 


\section{Penentuan Efisiensi Mikrokapsul}

Efisiensi mikrokapsul ditentukan dari jumlah likopen yang berada dalam mikrokapsul maupun likopen yang menempel dipermukaan mikrokapsul. Analisis likopen dilakukan menggunakan metode spektrofotometri likopen tersalut tepung rumput laut sebanyak $1 \mathrm{~g}$ ditambahkan heksan sebanyak $10 \mathrm{ml}$, kemudian dikocok dengan menggunakan mesin kocok agitasi $250 \mathrm{rpm}$ selama 20 menit. Ekstrak yang diperoleh diukur volumenya dan diukur absorbansinya pada panjang gelombang $470 \mathrm{~nm}$. Kadar likopen dihitung dengan menggunakan persamaan berikut:

$$
X=\frac{A \times Y \times f p}{E_{1}^{1 \%} \times b}
$$

Di mana:

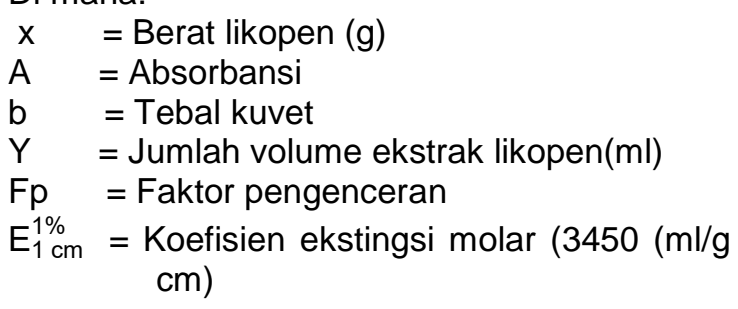

Efisiensi mikrokapsul dihitung mengikuti metode perhitungan Hardi et al. (2013) dengan persamaan berikut:

\%Efisiensi $=\frac{\text { Massa ekstrak mikrokapsul }(\mathrm{g}) \times \frac{\mathrm{a}}{\mathrm{b}}}{\text { Massa ekstrak likopen awal }(\mathrm{g})} \times 100$ Keterangan :

$\mathrm{a}=$ Massa mikrokapsul total $(\mathrm{g})$

$\mathrm{b}=$ Massa mikrokapsul yang dianalisis $(\mathrm{g})$

\section{Penentuan Kinetika Degradasi Likopen Dalam Mikrokapsul}

Dalam menentukan kinetika degradasi diperlukan mikrokapsul likopen tersalut rumput laut dengan waktu penyimpanan selama 4 minggu pada suhu ruang. Selanjutnya kadar likopen ditentukan dengan persamaan berikut :

$$
\text { Kadar likopen }=\frac{\text { Berat likopen }(\mathrm{g})}{\text { Berat Mikrokapsul }(\mathrm{g})} \times 100
$$

Penentuan kinetika degradasi likopen ditentukan dengan cara nilai kadar ekstrak likopen tersalut tepung rumput laut setiap minggunya diplotkan pada kurva orde nol (kadar terhadap waktu), kurva orde satu (In kadar terhadap waktu), dan kurva orde dua (In/kadar terhadap waktu). Kurva yang menghasilkan garis linear dengan nilai koefisien determinasi $\left(R^{2}\right)$ tertinggi atau mendekati satu adalah kinetika terpilih. Selanjutnya umur simpan ditentukan dengan menggunakan metode orde reaksi. Kinetika degradasi mikrokapsul terpilih digunakan untuk menentukan umur simpan. Umur simpan dihitung dengan cara nilai kadar $30 \%$ dari ekstrak likopen diplotkan pada persamaan regresi $y=a x+b$ dari orde reaksi terpilih.

\section{HASIL DAN PEMBAHASAN}

\section{Rendemen Likopen Buah Tomat (Lycopersicum pyriforme)}

Ekstraksi likopen buah tomat merupakan proses penarikan kandungan likopen dari daging buah tomat. Ekstraksi likopen buah tomat dilakukan menggunakan teknik maserasi. Menurut Safitri (2013), pemurnian likopen kasar dilakukan dengan cara ekstraksi menggunakan pelarut heksan. Ekstraksi dengan menggunakan teknik maserasi dikarenakan oleh likopen merupakan 
senyawa yang mudah teroksidasi yang salah satunya disebabkan oleh suhu. Pada saat maserasi, pelarut akan menembus dinding sel dan masuk kedalam rongga sel yang mengandung zat aktif yang selantunya terlarut. Adanya perbedaan konsentrasi antara zat aktif di dalam dengan di luar sel, maka akan terjadi difusi zat aktif ke luar sel (Ditjen POM, 2000). Ekstraksi likopen kasar diekstrak dengan pelarut campuran nonpolar heksan aseton.

Hasil ekstraksi likopen dari buah tomat diperoleh rendemen likopen kasar sebesar 8,29 \% pada perbandingan air/tomat $1: 1(\mathrm{v} / \mathrm{b})$ pada suhu $70^{\circ} \mathrm{C}$ selama 30 menit. Hasil yang diperoleh lebih tinggi dari hasil penelitian Daniel et al. (2017) pada kondisi yang sama, dimana hasilnya adalah 1,77\%. Faktor-faktor yang mempengaruhi rendemen yaitu suhu, teknik pengeringan, proses pengelupasan, 80-90\% kandungan likopen berada pada pericarp luar dan kulit, sehingga jika proses pengelupasan tidak tepat dapat membuat likopen ikut terbuang, begitupun pada pengaruh suhu. Makin tinggi susu dan makin lama waktu pemanasan maka makin besar kehilangan likopen (Hapsari, 2010).

\section{Rendemen Tepung Rumput Laut Eucheuma cottonni}

Berdasarkan hasil penelitian diperoleh rendemen dari rumput laut sebesar 53,33\%. Penelitian sebelumnya juga mengenai isolasi karaginan dari rumput laut Eucheuma cottonii oleh Lewerissa (2005) diperoleh rendemen sebesar 34,98\%. Penelitian Rizal et al. (2015) menghasilkan rendemen SRC sebesar $33,83 \%$ melalui proses ekstraksi menggunakan larutan alkali Kalium hidroksida pada konsentrasi $\mathrm{KOH} 8 \%$. Sehingga hasil penelitian ini lebih besar dibandingkan dengan hasil penelitian Rizal et al. (2015).

Ekstrak karaginan kasar merupakan hasil produk dari rumput laut melalui proses pemanasan menggunakan larutan alkali Kalium hidroksida $\mathrm{KOH}$ Mappiratu, (2009) dan Dewi et al., (2012). Mukti (1987) menjelaskan bahwa tingkat kelarutan senyawa karaginan dalam air dipengaruhi oleh beberapa factor, diantaranya temperature, $\mathrm{pH}$, tipe karaginan, dan zat-zat terlarut lainnya. Adanya gugus hidroksil dan sulfat yang bersifat hidrofilik pada struktur senyawa karaginan akan menyebabkan mudah larut air.

\section{Efisiensi Mikrokapsul}

Penentuan efisiensi mikroenkapsulasi atau efisiensi penyalutan dijadikan acuan utama untuk mengetahui jumlah zat aktif yang dapat disalut oleh enkapsulan. Efisiensi yang dimaksud dalam penelitian ini adalah berapa banyak ekstrak likopen yang tersalut dalam tepung rumput laut. 


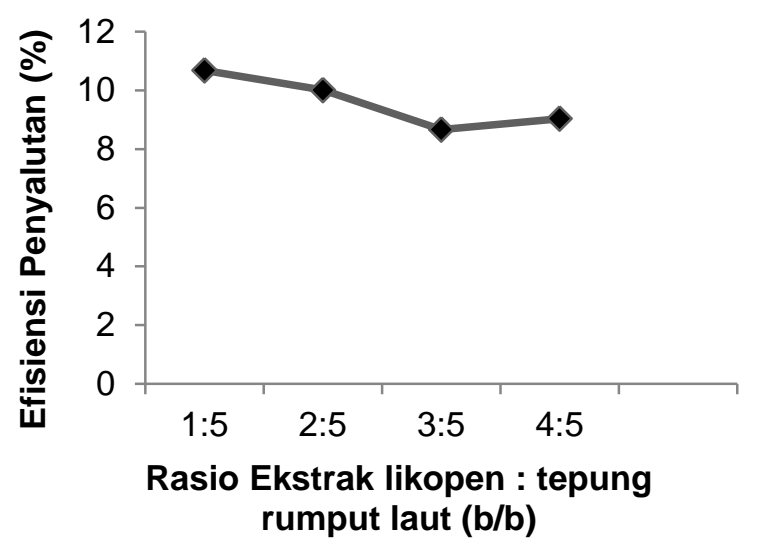

Gambar 1 Efisiensi penyalutan ekstrak likopen pada berbagai rasio ekstrak terhadap tepung rumput laut

Hasil pada Gambar 1 menunjukan bahwa efisiensi mikrokapsul ekstrak likopen tersalut tepung rumput laut yang dihasilkan tiap rasio 1:5, 2:5, 3:5 dan 4:5 masing-masing 10,686\%; 10,012\%; $8,668 \%$; dan 9,041\%. Hal ini menunjukan bahwa efisiensi mikrokapsul ekstrak likopen terhadap tepung rumput laut tertinggi yakni perbandingan 1:5 (b/b). Menurut Maulidyawati (2009) menyatakan bahwa salah satu faktor yang menyebabkan tingginya efisiensi mikrokapsul adalah perbandingan antara bahan penyalut dan bahan inti. Selanjutnya efisiensi likopen dalam mikrokapsul mengalami penurunan pada perbandingan $3: 5$, hal ini diduga karena sebagian likopen tidak tersalut saat proses mikroenkapsulasi. Menurut Nurlaili et al. (2014), penurunan efisiensi enkapsulasi dapat dipengaruhi oleh meningkatnya viskositas emulsi yang tinggi. Menurut Rosenberg (1985), viskositas emulsi yang tinggi akan mempengaruhi turunnya nilai efisiensi enkapsulasi. Hal ini akan menyebabkan banyak likopen yang tidak tersalut.

Berdasarkan analisis sidik ragam terhadap efisiensi penyalutan ekstrak likopen tersalut tepung rumput laut dengan berbagai rasio menghasilkan nilai signifikan $(0,116)$ atau lebih besar dari pada $\alpha(0,05)$, dengan demikian perlakuan rasio berpengaruh tidak nyata terhadap efisiensi penyalutan. Hal ini dapat diartikan bahwa penggunaan rasio 1:5 sampai 4:5 tidak berpengaruh terhadap efisiensi penyalutan dengan demikian perlakuan terpilih pada penelitian ini adalah penggunaan rasio 1:5 dengan nilai efisiensi tertinggi sebesar $10,686 \%$.

\section{Kinetika Degradasi Likopen dalam Mikrokapsul}

Analisis likopen tersalut ditentukan melalui metode spektrofotometri UV-Vis yang diukur pada panjang gelombang 470 $\mathrm{nm}$. Kinetika degradasi ditentukan pada orde nol, satu dan dua menggunakan kadar likopen dari perlakuan ekstrak likopen tersalut tepung rumput laut dari minggu ke-0 hingga minggu ke-4. Pemilihan orde nol, orde satu atau orde dua adalah berdasarkan keeratan hubungan koefisien determinasi $\left(R^{2}\right)$ yang lebih besar dari kurva hubungan antara lama penyimpanan dengan nilai kadar, In kadar dan 1/kadar. Berdasarkan hubungan kadar likopen terhadap waktu simpan ekstrak likopen tersalut tepung rumput laut pada suhu ruang diperoleh 
bahwa kadar likopen tersalut tepung rumput laut mengikuti orde nol dengan nilai $R^{2}=0.996$ yang lebih besar dibandingkan dengan orde satu $\left(R^{2}=0,987\right)$ dan orde dua $\left(R^{2}=0,971\right)$.

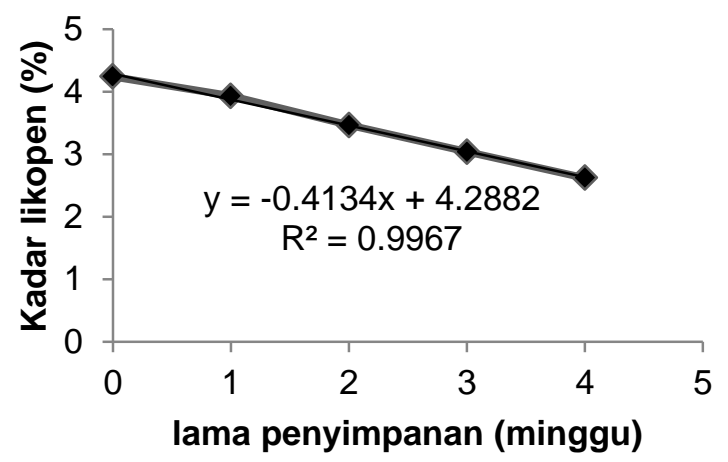

Gambar 2 Kurva hubungan antara kadar likopen tercampur rumput laut terhadap waktu simpan (orde nol).

Dimana orde reaksi ditentukan menggunakan pendekatan nilai $R$ yang menyatakan korelasi hubungan antara kadar likopen tercampur rumput laut terhadap waktu simpan untuk orde reaksi satu pada, 1/ kadar likopen tercampur rumput laut terhadap waktu simpan untuk orde reaksi dua dan kadar likopen tercampur rumput laut terhadap waktu simpan untuk reaksi orde nol (Gambar 2).

Nilai $R^{2} 0.996$ pada orde nol dapat diartikan bahwa 99,6\% waktu penyimpanan mempengaruhi retensi likopen, sedangkan $0.4 \%$ dipengaruhi oleh faktor lain seperti cahaya, $\mathrm{pH}$, dan lainlain. Hal yang sama ditemukan oleh Rahmat (2018) bahwa mikroenkapsulasi ekstrak likopen tersalut karaginan diperoleh dari kinetika degradasi orde nol $\left(R^{2}=0.939\right)$. Penelitian Sukriadi et al. (2013) yang mengkaji degradasi likopen tersaut maltodekstrin mengikuti orde reaksi nol $\left(R^{2}=0.922\right)$. Menurut Vargas dan Lopez (2002), degradasi akibat masa penyimpanan mengikuti orde reaksi nol. Jika laju degradasi mengikuti kinetika reaksi orde nol, berarti laju keusakannya bersifat eksponensial, namun pada akhirnya likopen tidak akan pernah mencapai titik nol tetapi hanya mendekati titik nol. Menurut Masitho (2013) likopen sensitif terhadap suhu. Sharma dan Mague (1996) menambahkan bahwa waktu penyimpanan berpengaruh nyata terhadap peningkatan degradasi likopen.

Likopen sebagai antioksidan mudah mengalami kerusakan yang disebabkan oleh suhu, cahaya, teknik pengeringan, penyimpanan, asam dan logam-logam berat. Adanya ikatan ganda terkonjugasi, menyebabkan likopen peka terhadap oksidasi terutama dalam bentuk padat, oksidasi likopen akan berlangsung lebih cepat. Hasil analisis kadar likopen selama penyimpanan suhu ruang menunjukan kerusakan/penurunan likopen pada penyimpanan suhu ruang mengikuti reaksi orde nol. Asumsinya adalah apabilah konsentrasi likopen < 30\% atau tingkat kerusakan likopen telah mencapai $70 \%$ maka formula tersebut tidak baik lagi (Sukriadi, et al. 2013). Umur simpan dari mikrokapsul likopen tersalut tepung rumput laut pada suhu ruang adalah sekitar 7,3 minggu yang diperoleh dari reaksi orde nol, dimana $y=-0,413 x+$ 4,288 dengan $R^{2}=0.996$. Hasil penelitian Daniel et al. (2017), menunjukan bahwa 
umur simpan likopen tercampur maltodekstrin pada rasio $10: 10$ atau $1: 1$ pada suhu ruang adalah 11,43 minggu.

\section{KESIMPULAN}

Rasio campuran ekstrak likopen tersalut rumput laut yang dapat menghasilkan efisiensi penyalutan terbaik adalah pada perbandingan 1:5 sebesar $10,686 \%$ dan kinetika degradasi likopen tersalut tepung rumput laut mengikuti kinetika reaksi orde nol.

\section{UCAOAN TERIMA KASIH}

Terimaksih sebesar-besarnya diucapkan kepada Jaya Hardi, S.Si., M.Si. yang telah memberikan banyak bantuan selama penelitian berlangsung.

\section{DAFTAR PUSTAKA}

Caldeira, RL. 2007. First record of mollusks naturally infected with angiostrongylus cantonensis. Brazil. Mem inst oawaldo cruz 102 : 887889.

Daniel, K., Mappiratu., Sumarni, N K. 2017. Penentuan Masa Kadaluarsa Likopen Dari Buah Tomat (Lycopersicum pyriforme) Tercampur Maltodekstrin Dalam Kemasan Kapsul. KOVALEN, 3(3)" 223-233.

Dewi, E.N; Darmanto Y.S., Ambariyanto. 2012. Characterization and quality of semi refined carrageenan (SRC) products from different coastal water based on fourier transform infrared technique. J. Coastal Development. $14: 25-31$.

Ditjen POM.1986. Sediaan Geletik. Jakarta: Depertemen Kesehatan RI.
Giovannucci, E. 1999. TomatoesTomatobased ProductsLycopene and Cancer Review of the Epidemiologic Literature. J. Natl Cancer Inst. 91:317-331.

Glicksman, M. 1983. Food Hydrocolloids. Volume I. CRC Press Boca Raton, Florida. pp 207.

Hapsari, C.M.M.A. 2010. Pengaruh Pemberian Jus Tomat Terhadap Kerusakan Histologist Alveolus Paru Mencit Yang Dipapar Asap Rokok. Skripsi. Surakarta: Fakultas Kedokteran Universitas Sebelas Maret Surakarta.

Hardi, J., Sugita, P., Ambarsari, L. 2013. Dissolution Behavior, Stability And Anti-Inflammatory Activity Of Ketoprofen Coated Tripolyphosphate Modified Chitosan Nanoparticle. Indo. J. Chem, 13(2), $149-157$.

Irsyad, M. 2017. Produksi Antosianin Tersalut Maltrodekstrin dari Kelopak Bunga Rosella dan Aplikasinya dalam Pangan Fungsional. Tesis. Palu: Universitas Tadulako.

Lachman L., Lieberman H.A., Kanig J.L. 1994. Teori dan Praktek Farmasi Industri diterjemahkan oleh Suyatni S., Edisi II. Jakarta: UI Press, hlm 651- 662 .

Lewerissa. 2005. Pengaruh Umur Panen Eucheuma cottonii Terhadap Karakteristik Karagenan dan Edible Film yang Dihasilkan. Thesis Yogyakarta: Program Pasca Sarjana. Universitas Gadjah Mada.

Maulidyawati N. 2009. Mikroenkapsulasi ibuprofen dengan penyalut polipapduan poli-(asam laktat) dan polikaprolakton. Skripsi. Bogor: Fakultas Matematika dan IImu Pengetahuan Alam, Institut Pertanian Bogor. 
Nurlaili, F. A. Darmadji, P. dan Pranoto, Y. 2014. Mikroenkapsulasi Oleoresin Ampas Jahe (Zingiber Officinale Var.Rubrum) Dengan Penyalut Maltodekstrin. AGRITECH, 34(1).

Rahmat, 2018. Penggunaan Karagenan Sebagai Penyalut Ektrak Likopen Buah Semangka (Citrullus vulgaris schard). Skripsi. Palu: Program Studi Kimia, Fakultas Matematika dan IImu Pengetahuan Alam, Universitas Tadulako,

Rizal, M., Mappiratu, dan A. R. Razak. 2015. Optimalisasi Produksi Semi Refined Carrageenan (SRC) dari rumput laut (eucheuma cottoni). KOVALEN, 2(1):33-38.

Safitri, N. 2013, Kajian Aktivitas Antioksidan Ekstrak Likopen dari Buah Tomat (Lycopersicum pyriforme) Selama Penyimpanan Pada Suhu Ruang. Skripsi. Palu: Program Studi Kimia, Fakultas Matematika dan IImu Pengetahuan Alam, Universitas Tadulako.

Sukriadi., Mappiratu., Nurhaeni. 2013. Penggunaan Maltodekstrin Untuk Meningkatkan Masa Simpan Likopen Buah Semangka (Citrullus vulgaris Schard). Jurnal Natural Science Vol. 2(1): 35-45.

Vargas, F. D dan Lopez, O. P. 2002. Natural Colorants for Food and Nutraceutical Uses. New York: CRC Press.

Yuan Y., Yanziang G., Jian 2. Like M. 2008. Characterization and stability evaluation of b-carotene nanoemulsion prepared by high pressure homogenization under various emulsifying conditions. Food research international $41:$ 61-68. 